Paper received: June $26^{\text {th }} 2015$

Paper accepted: October $13^{\text {th }} 2015$

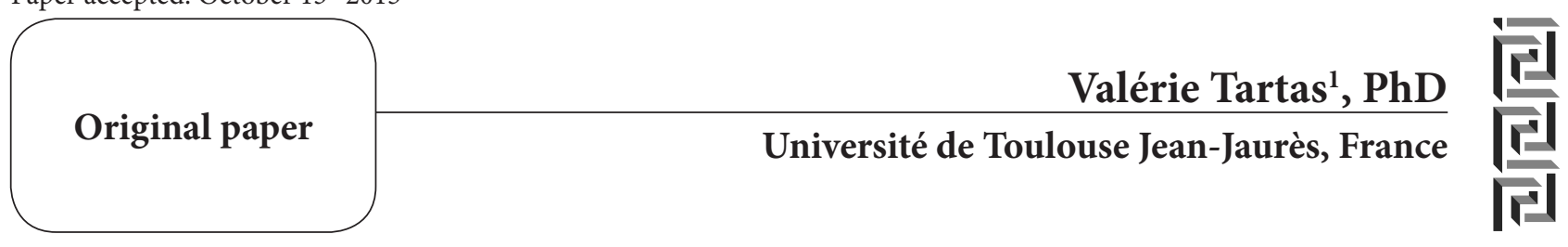

DOI:10.5937/inovacije1503050T

\title{
Learning science with dialogical maps
}

\begin{abstract}
The development of children's concepts is often still studied without taking into account school practices, namely, the verbal and instrumental activities in which these concepts develop. The present research is rooted in a Vygotskian perspective that defines thinking and its dynamics within the semiotic contexts where they take place. The article aims at showing how pupils were guided by their teacher to adopt an inquiry-and argumentative-based approach to learning science. Software developed to support argumentation and learning - an argumentative map called Digalo that provides a visual representation of the discussion - was used in the classroom by teachers and students to learn about astronomy. The data presented here were extracted from a European project (Escalate) which aimed to enhance science learning through argumentation and inquiry activities (Andriessen, Baker \& Suthers, 2003; Muller Mirza \& Perret-Clermont, 2008; Muller Mirza, Tartas, Perret-Clermont \& De Pietro, 2007). Three elementary classes (grades 3, 4 and 5) participated in the study and were led to explain "why are there seasons?" in the course of different phases of debates guided by the teacher and mediated by argumentative maps. General quantitative results based on the comparison of pre-test and post-test scores showed that the students in grades 4 and 5 improved their knowledge whereas the $3^{\text {rd }}$ grade students did not progress. A more detailed analysis of the different phases of the study was then carried out, focusing on the evolution of children's understanding of the seasons through the analysis of their productions (the structure and argumentative contents of their argumentative maps) and on how the $5^{\text {th }}$ grade teacher scaffolded his students' sessions. The results showed that elementary school students can learn from debate oriented by argumentative maps and guided by the teacher. The roles of argumentative maps and teacher's scaffolding in learning and thinking processes are discussed from a sociocultural perspective.
\end{abstract}

Key words: learning in science, argumentation, semiotic tools and mediations, argumentative map.

1 valerie.tartas@univ-tlse2.fr 


\section{Introduction}

The research presented here aims to show that even in elementary school where children have not yet developed scientific concepts ${ }^{2}$, they can engage in a participatory way of doing science and can develop discursive practices as scientists (namely negotiating the meaning of a phenomenon through debate and dialogues mediated by cultural tools such as scientific data or schemas, drafts, etc.). "Learning and thinking are always situated in a cultural setting and always dependent upon the utilization of cultural resources" (Bruner, 1996, p. 4). This proposition was illustrated by studying some intermediate cuvres (Meyerson) by elementary school children in the course of a scientific activity that consisted in understanding the seasons. Three classes of $3^{\text {rd }}$, $4^{\text {th }}$ and $5^{\text {th }}$ grade students participated in constructing an argumentative map and then re-using it in a subsequent session guided by their teacher. Our research questions are: what practices take place when a particular tool is used in class to learn astronomy? And how are durable traces of scientific activity and thinking processes materialized in argumentative maps used by the teacher to develop the children's understanding of a specific phenomenon, i.e., the seasons?

In psychology, the role of materiality or objects in shedding light on the development of knowledge is generally considered subsidiary. In Piagetian theory, for example, objects are pretexts for studying children's individual competencies; they are not taken into account as social and historical entities. Being able to use them reveals the stage of thinking reached by the child. Other authors, however, have stressed the need to take objects and, more broadly, all mediations (material or conceptual) into account in order to understand where knowledge comes from (Baucal, 2012; Perret \& Perret-Clermont, 2011; Sørensen, 2009). This is also the case in the CHAT (Cultural Historical Activity Theory) perspective

2 According to Vygotsky's definition, scientific concepts emerge during adolescence.
(Cole \& Engestrom, 1995; Cole 1996; Engestrom, 1987). Following Vygotsky, these authors assign a central role in learning situations to social interactions in which students and teachers have the opportunity to reflect on their problem-solving strategies by engaging in a reflexive written or oral activity. In this perspective, activities that use intermediate artefacts to support social interactions are central in the meaning-making process. One such artefact is Digalo ${ }^{3}$, a software designed by researchers in psychology, education, communication and computer sciences to support argumentation in learning science. The underlying assumption was that debate and argumentation in class might become thinking tools that enhance learning. One of the aims of this research was to invite children to engage in scientific debates, as practicing scientists do, relying on the appropriation of concepts and the use of valid resources (for a detailed presentation of the role of the software, see Andriessen, Baker \& Suthers, 2003; Muller-Mirza \& Perret-Clermont, 2008). Drawing on Vygotsky's thesis that thinking is semiotically mediated (Vygotsky, 1978), we hypothesized that the external representation of dialogues in argumentative maps (Digalo) could transform exchanges in the three school grades studied and thereby help to co-construct shared knowledge or ideas.

The originality of the Escalate research project conducted in Toulouse (France) was to propose this tool in an elementary school in order to study how teachers and their students used it to achieve a scientific understanding of the seasons. Three different grades took part in the research (Grades 3, 4 and 5) working on the cycle of seasons and the day/night cycle. We present here only part of the research project - the way children and their teacher co-constructed a shared understanding of the phenomenon of seasons by analysing the mediations used. We first present some theoretical underpinnings of the study, then the methodology used and

3 Digalo was developed in the Dunes project IST-2001-34153 and was tested in Escalate (Enhancing SCience Appeal in Learning through Argumentative inTEraction) in science learning. 
the main results regarding the role of Digalo maps in the teaching-learning situations.

\section{Reasoning in astronomy}

\section{Naïve or everyday knowledge versus scientific knowledge}

In developmental psychology, studying children's initial knowledge in astronomy is based on the identification of the naive knowledge they have of the world. Vosniadou, Skopeliti \& Ikospentaki (2004) showed that 6- to 12-year-old children's naïve representations about the shape of the Earth evolved as a function of different models: the first models represented the Earth as a disc or rectangle whereas the final model matched the scientific one, i.e. a spherical representation of the Earth. Between these two extremes were intermediate models that integrated new knowledge acquired in class into the initial or naïve knowledge. Children appeared to have a sort of naïve theory about the shape of the Earth, based on two presuppositions: "what looks flat is flat" and "what is not held up, falls down". In this cognitivist perspective, the focus is on the organisation and structuration of knowledge and its evolution during development. This perspective, often designated as conceptual change, tries to explain the difficulties met by children and adults based on their cognitive functioning. According to this theory, this intra-individual level of analysis could explain the difficulties people encounter in understanding a scientific phenomenon.

Another perspective consists in reconsidering the distinction made by Vygotsky between everyday concepts and scientific concepts and in redefining developmental psychology as a psychology of education or a psychology of teaching-learning situations and not only of an individual subject working alone. Schoultz, Säljö \& Wyndhamn (2001) showed, for example, that it is necessary to take not only discourse practices seriously into account but also artefacts such as the globe in order to understand how children reason and develop their reasoning regarding the Earth. Most of the time, except in situated and distributed approaches to cognition (Hutchins, 1995; Lave, 2011), these constructions have been studied in a decontextualised manner, that is to say outside the discursive and mediated activities in which they were constituted.

The present study adopts a Vygotskian approach, which posits that the activity of thinking and its dynamics or movements cannot be studied independently from the social, material and semiotic context from which they emerged (Moro, Schneuwly \& Brossard, 1997). This is in line with the idea of a "semiotic ecology" (Enyedy, 2005) where talk, gestures, texts, graphics as well as body postures, material environment and history are taken into account (p.432). In order to understand the meaning-making process of a phenomenon, it is necessary to take seriously into account both materiality and semiotic tools as resources that can be the stage for another resource (p.432). In a sense, like Latour's (1987, 1988) definition of science as an argumentative social process that is never stabilized, a process of constructing, defending and challenging arguments about the nature of the world is used here. His proposition of mapping controversies (cartographie des controverses in French) in science seems to be both a methodology to learn about the complexity of scientific issues and a semiotic system to represent the links or networks between the different viewpoints of the actors involved in the process of doing science. Digalo allows users to construct maps of dialogues and thus supports doing science dialogically by visualizing the ongoing discussion about a scientific phenomenon. Studying argumentative maps in practice in different classes will illustrate whether or not this kind of tool supports the meaning-making process for students.

So following Latour, if doing science means engaging in argumentation for practicing scientists, children who learn to practice science need to learn how to construct, negotiate, defend and challenge 
arguments (Danish \& Enyedy, 2015). The developmental literature in psychology showed that children as young as three years old are able to provide justifications for their actions (Dunn \& Dunn, 1987). Later, they also become able to adapt their justifications to the audience and the context (Orsolini, 1993). As we discussed elsewhere (Muller-Mirza, Perret-Clermont, Tartas \& Iannaconne, 2009), argumentation is a socially and culturally situated activity. Children learn to argue in everyday contexts and also learn to argue differently at school depending on the topic under study. Doing astronomy can be defined as participating in a social dialogical process with partners who do not always share the same background, knowledge and theories, where negotiations are at stake using different kinds of cultural resources. In the next part, we will explore the role of mediations in such a learning process.

\section{Learning from social situations through computers}

Learning has been defined in a situated perspective as learners' participation in inquiry- and discourse-based activities in science that bring together social interactions and the technological, material and symbolic resources available in the environment. Learning processes are not determined but are shaped by the social and physical affordances of the systems used by learners. Disagreements and their resolution, socio-cognitive conflicts (Baucal, Arcidiacono \& Budjevac, 2013; Doise, Mugny \& Perret-Clermont, 1975; Perret-Clermont, 1979/2000) and verbal exchanges (Jaubert, 2007) play a central role in learning. Argumentation in class is also a discursive activity that leads to learning and knowledge development (Andriessen, Baker \& Suthers, 2003; Douaire, 2004; Muller-Mirza \& Perret-Clermont, 2009).

Research in CSCL (Computer Supported Collaborative Learning) has shown that technological, material, and social resources shape how users think about technology. As a result, software developers design interfaces that are intended to structure social interactions as they can generate learning for the users and orient the structuration of the argumentation. The software provides visual support for the discussion through the construction of argumentative maps or discourse maps. The externalisation of arguments and claims in a visual representation of knowledge has both advantages and constraints for debating and learning. These argumentative maps were first used as a means of communication or as a way of recording argumentative exchanges and then they became resources (both stimuli and guides) for conversation and reasoning (Roschelle, 1994). Suther (2003) showed for example how different computer-based representational shapes allowed the construction and manipulation of external representations that mediated collaborative interaction, a process he referred to as representational guidance. These representational tools provided the learners with the means of sharing their understandings and once shared, their understandings became open to question and usable by everyone taking part in the discussion. They became part of a shared context as objects of knowing. Representational guidelines play three main roles according to Suthers (2003, p.31): (1) they can initiate negotiations on the meanings at stake in the debate. For example when learners want to transform one representation or add a new idea they are obliged to agree with each other, which leads to negotiations about the representations used; (2) like deictics in writing, they have a deictic function since their components (i.e., arrows) make it possible to refer to what has been proposed earlier. An agreement or disagreement between two ideas or arguments can be pinpointed by using arrows to link two different shapes in the graphical discussion; (3) they provide a foundation for an explicitly shared awareness or a collective memory (p.31); shared representations may serve as memories for the group and they become always accessible for future exchanges. 
As the present research concerns elementary school pupils and not more advanced students as is usual in CSCL studies, not all the functionalities of Digalo were used by the teacher and students. Thus, the shapes denoting different language acts were reduced to two or three: one for saying "I have an idea" or "I have a question..." and one for saying "I have a hypothesis" but in fact these shapes were used indifferently by the users. What serves as meditational means in our study is not the fact that shapes mediate different statuses of knowledge (such as hypothesis, argument, belief, question, counter-argument, etc.), it is rather the possibility of tracking the main ideas written in undifferentiated shapes and the possibility of going back to earlier elements in the conversation that serves as a tool to think about and explore in depth the problem under study. So writing her/his own idea, sharing it with others, questioning it, justifying it and trying to defend it or reviewing it depending on the different points of view and exchanges may lead students to develop a better understanding of the seasons. Suther (2003) pointed out that the units of knowledge made visually salient in the representational space become a more important object of negotiation than the units that were not challenged, discussed and linked to others.

Based on the thesis of the semiotic mediation of the mind, we hypothesized that participating in a debate mediated by Digalo followed by a reflexive step on the argumentative maps considered as a product or intermediate state of thinking (the maps were printed and read and examined by the students and their teacher), can be conducive to learning in science. A great deal of research in CSCL has shown the benefits of synchronous sessions with argumentative tools but very few studies have examined how the argumentative map as a process of meaningmaking can become a product from which another thinking activity may emerge between students and their teacher. What kind of practices take place when the teacher uses Digalo in an elementary astronomy class? To answer this question, we monitored the way children and teachers used Digalo in the course of different kinds of learning activities aiming at helping students to acquire a "scientific culture", i.e. to be able to propose a hypothesis, to discuss it with others in order to improve it, and to use acceptable and evaluable sources to support their viewpoint.

We focused mainly on the transition from a collaborative dialogical written activity - synchronous debate through an argumentative map - to another collective dialogical activity directed by the teacher and mediated by a printed argumentative map on which students were invited to assess the argumentation and the knowledge used. We assumed that this space of negotiation, supported by argumentative maps in both synchronous and asynchronous (afterthought traces of activity) use, and guided by the teacher would lead to a reflexive activity about knowledge and argumentation. It is not only the semiotic activity based on this kind of map that generates such a reflexive posture but the combination of these varying forms of work guided by the teacher that can lead to such a inquiry attitude towards others' and towards their own ideas.

\section{METHODOLOGY}

\section{Participants}

Three grades in an elementary school in the suburb of Toulouse participated in the study: 25 grade 3 students and their teacher, 23 students in a double grade (grades 4 and 5) and their teacher, and 28 Grade 5 students and their teacher. Different artefacts (language as well as various semiotic tools such as maps, tables, gestures, etc.) were used to answer the question: why are there seasons? Teachers and researchers co-constructed the class sessions and chose the different tools distributed to the students in order to support the scientific approach based on the emergence of conflicts or contradictions at different steps in the learning process. 


\section{Material}

The students took part in the activity 'doing astronomy' by following different sessions in the learning sequence in which various resources were proposed: a scientific figure representing the distance between the Earth and the sun at the different equinoxes; the uses of the software Digalo. The teachers and the students also used the blackboard and a globe. During the small group sessions, the students used their notebooks to write down explanations that completed/supported their verbal exchanges.

We focus particularly on (a) the argumentative maps in-the-making (in synchronous session) as the visualization of the discussion in order to represent different points of view and their relations; (b) the printed argumentative maps as specific meditational tools (tool of the tool in a sense) because they can be used as discursive tools to support an initial understanding of the object -seasons- and as a discursive product when they become an object for a new activity (evaluation of the propositions in the map).

\section{The learning situation and the unit of analysis}

A learning sequence comprised several sessions during which different activities were proposed in order to see whether or not students can engage in an inquiry- and argumentation-based approach to science. These activities - formulating a hypothesis, explaining seasons using different documents, debating in class, debating with Digalo, reusing a collaborative work materialized on an argumentative map in order to start a new debate - were studied as mediated actions in context (the unit of analysis suggested by Cole, 1996). The analyses of these different actions concern two planes of cognition: a plane with an analysis of the dynamics of argumentation (Argument $\wedge$ Reply^Counter-Argument, Leitao 2000) and a conceptual plane, the di- mension of meaning-making of the phenomenon "seasons". But as these mediated actions are guided by the teacher, the processes of argumentation and of co-constructing meanings of the seasons were also studied with respect to the teacher's actions and in particular how the teacher scaffolded students' argumentative and conceptual activity.

Figure 1 presents the different steps of the learning sequence. (1) In the first phase, students were asked to answer different questions about astronomy in order to assess their comprehension of the seasons and of the day/night cycle, etc. (2) In the second phase, small groups of four students (with different levels of understanding, based on the results of the questionnaires in phase 1) had to write hypotheses to explain "why is it hotter in summer than in winter?" after having worked together on a figure representing the distance from the Earth to the sun. (3) The third phase consisted of a whole-class debate on the question "why are there seasons?" as a point of departure and in which all the groups put forward their hypotheses that had been formulated in the previous phase. (4) A debate through Digalo then took place, initiated by a question or a proposition, which was not the one on which there was a consensus in the small groups in phase 2. (5) The fifth phase was a map-oriented discussion in small groups (the same during all the phases): two reconstructed maps based on the maps developed in phase 4 were proposed in order to initiate another debate. (6) A final collective debate based on these two argumentative maps was orchestrated by the teacher. (7) Students were individually asked the same questions as in phase 1, as a sort of post-test (even if it can also be defined as a learning phase as we discussed elsewhere; see Tartas \& Perret-Clermont, 2012; Tartas, Baucal \& Perret-Clermont, 2010). All of these steps were videotaped and transcribed. In this article, we will focus mainly on the fourth phase (in which the maps were produced by the students) and on the following phases where they were re-used. The analysis of the last collective debate (step 6) has been reported elsewhere (Tartas \& Simonneaux, 2015), so 
will not be presented here in detail. Rather, we used the epistemic obstacles identified in this first analysis (Tartas \& Simonneaux, 2015) as indicators to study the co-construction of the scientific meanings of the seasons through several argumentative sessions (from 2 to 5 ). We focused our analysis mainly on some of these "epistemic obstacles" such as the movements of the sun/the movements of the Earth, the tilt of the earth/ the angle of the sunbeams, the "speed" of the Earth (the fact that the Earth can rotate faster or more slowly).

\begin{tabular}{|c|c|c|}
\hline Phase & Nature of the task & Data \\
\hline 1. Individual work (pre-test) & $\begin{array}{l}\text { To explain the planets' } \\
\text { moves, seasons, day and } \\
\text { night cycle... }\end{array}$ & First written production \\
\hline $\begin{array}{l}2 \text { (a) collective in the class } \\
\text { 2. (b) collective work in group } \\
\text { of } 4 \text { (heterogeneous) }\end{array}$ & $\begin{array}{l}\text { Initial question + first } \\
\text { explanations } \\
\text { Putting foward a hypothesis } \\
\text { (distance document) }\end{array}$ & $\begin{array}{l}\text { oral exchanges in the class } \\
\text { and within small groups } \\
\text { (video-recorded) + written } \\
\text { production (joint } \\
\text { hypotheses) }\end{array}$ \\
\hline $\begin{array}{l}\text { 3. Collective debate in class - } \\
\text { joint setting }\end{array}$ & $\begin{array}{l}\text { To confront groups' } \\
\text { hypotheses to outline the } \\
\text { diversity of explanations }\end{array}$ & $\begin{array}{l}\text { Oral exchanges in class } \\
\text { (video-recorded) }\end{array}$ \\
\hline 4.Digalo session in group of 4 & $\begin{array}{l}\text { To debate from another } \\
\text { hypothesis than the one } \\
\text { proposed }\end{array}$ & $\begin{array}{l}\text { Writen exchanges on digalo + } \\
\text { oral exchanges (video- } \\
\text { recorded) }\end{array}$ \\
\hline 5. Small group on maps & $\begin{array}{l}\text { To evaluate two } \\
\text { argumentative maps }\end{array}$ & $\begin{array}{l}\text { Oral exchanges (video- } \\
\text { recorded) }\end{array}$ \\
\hline 6. Collective in the class & Debate on the maps & $\begin{array}{l}\text { Oral exchanges (video- } \\
\text { recorded) }\end{array}$ \\
\hline 7. Individual work (post-test) & Same as 1 & Written production \\
\hline
\end{tabular}

Figure 1. The different phases of the learning sequence regarding the nature of the task and the kind of data.

\section{Results}

\section{General results (comparison of phases 1 and 7)}

The analysis of the students' answers to the questions concerning their knowledge about the solar system (first and last phases of the learning sequence) led to the conclusion that the grade 5 students and the double $4^{\text {th }}$ and $5^{\text {th }}$ grade students im- proved their knowledge about the seasons (comparisons of scores between pre- and post-tests: grade $5: \mathrm{t}=2.585, \mathrm{p}=0.017$ and grade $4-5^{\mathrm{th}}: \mathrm{t}=2,750$, $\mathrm{p}=0.010$ ). More particularly, the most frequently used argument in phase one (the distance) to explain the fact that it is hotter in summer than in winter, was less frequent in the last phase for these two grades. Only the $3^{\text {rd }}$ grade students did not progress 


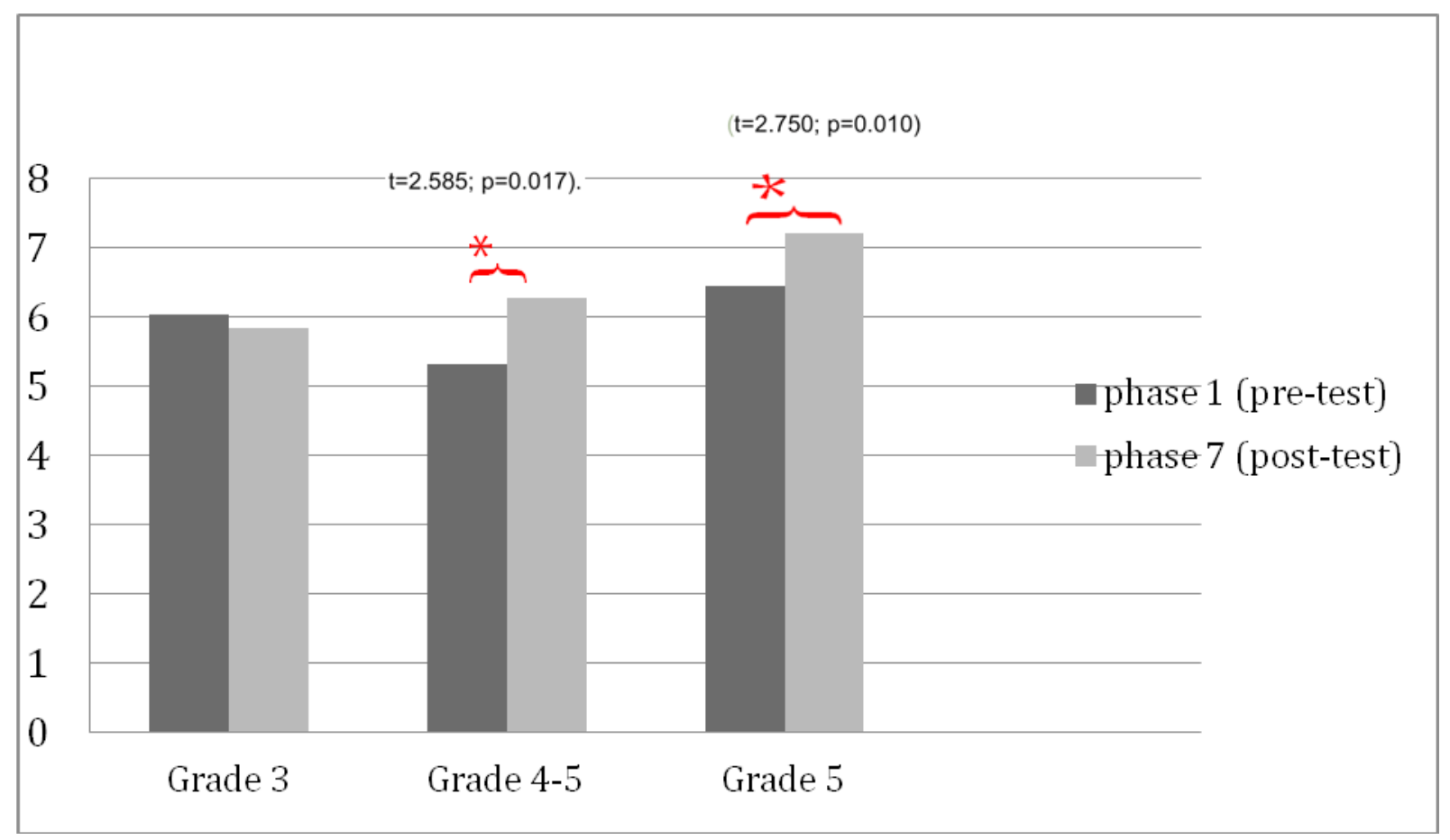

Figure 2. Evolution of the score of understanding the seasons from pre-test (phase 1) to post-test (phase 7)

between phase 1 and phase 7 . However, this general analysis tells us nothing about what happens during the different argumentative phases of the learning sequence. We therefore undertook more detailed analyses to examine (a) the different hypotheses proposed by the groups of students in the three elementary grades; (b) the way they discussed them through argumentative discussion online (Digalo session phase 3 ); (c) the way the $5^{\text {th }}$ grade teacher and his class co-constructed a shared explanation of the seasons by using the argumentative maps.

\section{Different kinds of hypotheses depending on the school grade}

If we examine first the hypotheses proposed by the students after phase 2 , where they worked in small groups of four students on a scientific document (a figure representing the distance from the sun to the Earth at the different equinoxes) and after the first whole-class debate (phase 3), it was the hypothesis of distance that was preferentially used by the students even though they had a document that directly contradicted this proposition. This contradiction, deliberately introduced by the teacher, did not achieve the intended effect from the students' perspective as they did not use it at the beginning of the learning sequence.

The $3^{\text {rd }}$ grade students proposed two hypotheses: (a) the Earth goes faster in winter than in summer and (b) the Earth is nearer the sun in summer.

The $4-5^{\text {th }}$ grade students proposed two hypotheses: (a) the Earth is nearer the sun in summer and (b) the days are shorter in winter because the Earth is tilted.

The $5^{\text {th }}$ grade students developed four hypotheses: (a) summer is due to the fact that the Earth approaches the sun; (b) half of the Earth is lit 
by the sun and the other half not; (c) the hot season is due to the fact that the sun is higher; (d) the sunbeams arrive straight on the Earth in summer.

\section{Examples of argumentative maps at the three elementary school levels}

These different hypotheses were re-used to initiate the debate via Digalo software in phase 4: the students discussed in pairs via the software in the same small groups as those initially formed in phase
2. Three examples of argumentative maps are shown to illustrate the kinds of maps elaborated by the students as a function of their grade (see Figures 3, 4 and 5). We analysed the maps using Leitao's (2000) patterns of Claim ${ }^{\wedge}$ Counter-Claim ${ }^{\wedge}$ Reply in order to shed light on argumentative dynamics and we also tried to identify the different themes proposed and negotiated during the various debates.

The way $3^{\text {rd }}$ grade students used Digalo is specific: they did not justify their propositions and sim-

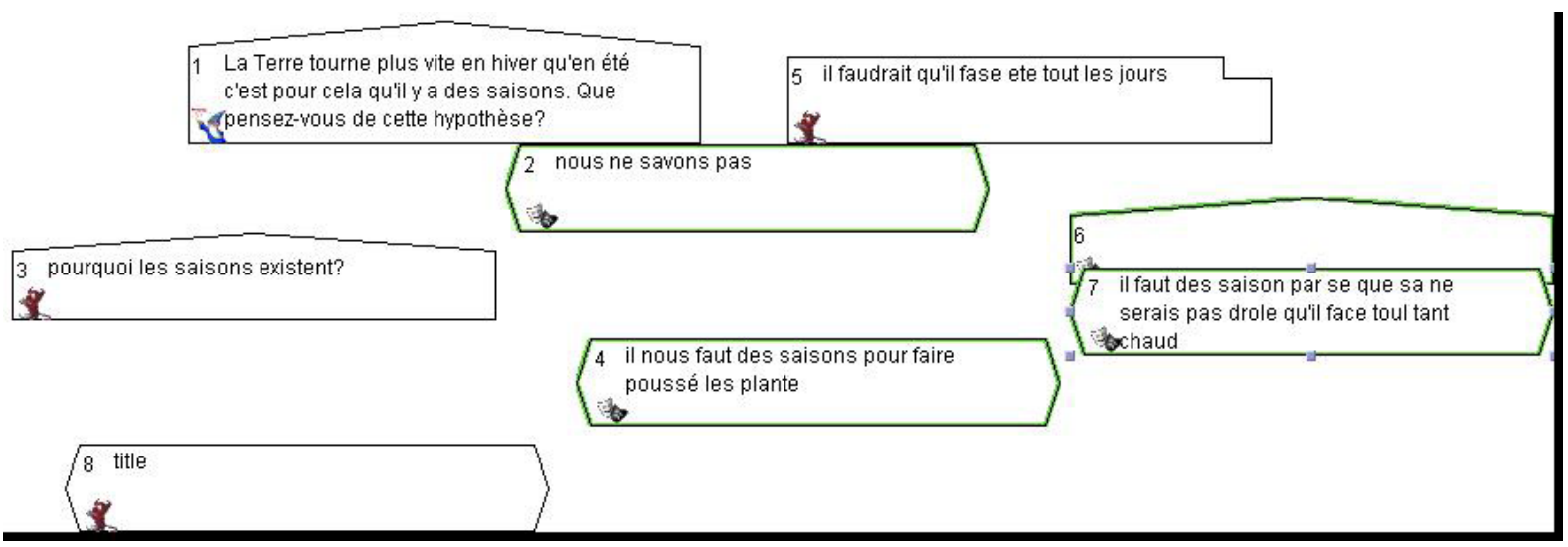

Figure 3. Example of an argumentative map in grade 3 (phase 4)

Legend: translation of the map

1.The Earth turns faster in winter than in summer that's why there are seasons

2.we don't know

3.why do seasons exist?

4. seasons are needed to make the plants grow

5.It should be summer everyday.

6.

7.we need seasons because it would not be funny if it is always hot.

ply juxtaposed their ideas without linking them up. Furthermore, whatever the hypothesis proposed, as here in figure 3 "the Earth goes faster in winter than in summer, that's why there are seasons", grade 3 students proposed functional explanations such as "seasons are necessary to make plants grow!" This proposition was not challenged or taken up as an object of discourse. Each of the participants in the debate wrote a proposition without any link with what had been previously proposed.

In the $4-5^{\text {th }}$ grade, the argumentative maps were not more fully developed than in the $3^{\text {rd }}$ grade 
2 heureusement qu'ily a des pays froid car sinon la terre serais tout le temps chaudea

oui car les pays du bas ne sont pas atteint par les rayons du soleil.
Nous n'avons pas tous le même

ensoleillement car les pays ne sont pas

tous droits. Ceux du bas auront moins de

soleil I'hiver. Qu'en pensez-vous?

\section{5 l'ensoleillement et faible l'hiver car les raillon du soleil les ateigne moin}

Figure 4. Example of an argumentative map in the 4-5th grade

Legend: translation of the map

1. We do not have the same sunlight because not all countries are straight. The ones in the bottom will have less sun. What do you think about that?

2.fortunately there are some cold countries otherwise the Earth would always be hot.

3.yes because the sunbeams can't reach the countries at the bottom .

4.-

5.the sunlight is weak in winter because the sunbeams reach them less.

but the students tried to answer the question that can be reformulated as: what are the origins of the seasons? The initial hypothesis presented in figure 4 was "we do not all receive the same amount of sunlight because the countries are not all straight on. The ones that are at the bottom have less sun in winter" (see figure 4, number one). This hypothesis was not taken into account by the students but they tried to answer why there are seasons or they tried to justify their proposition. In another argumentative map, the following hypothesis "the days are shorter in winter because the Earth is tilted" was challenged, with opponents "I think it is wrong because in that case the days would also be longer in summer" and defenders "we think it is true because the sun rises later in winter and sets earlier". Answers at this level begin to be justified and co-exist with propositions that are juxtaposed.

In Figure 5 there are seventeen propositions, some linked by arrows. The format of the discussion through Digalo was rather Claim ${ }^{\wedge}$ CounterClaim^^Reply (Leitao 2000; Muller-Mirza, Tartas, Perret-Clermont, \& De Pietro, 2007). The students engaged fully in a sort of evaluative process about what had been said and why. They asked questions when it was not clear or when they needed further information. Argumentative maps become richer in quantity and quality as the school level increases. 


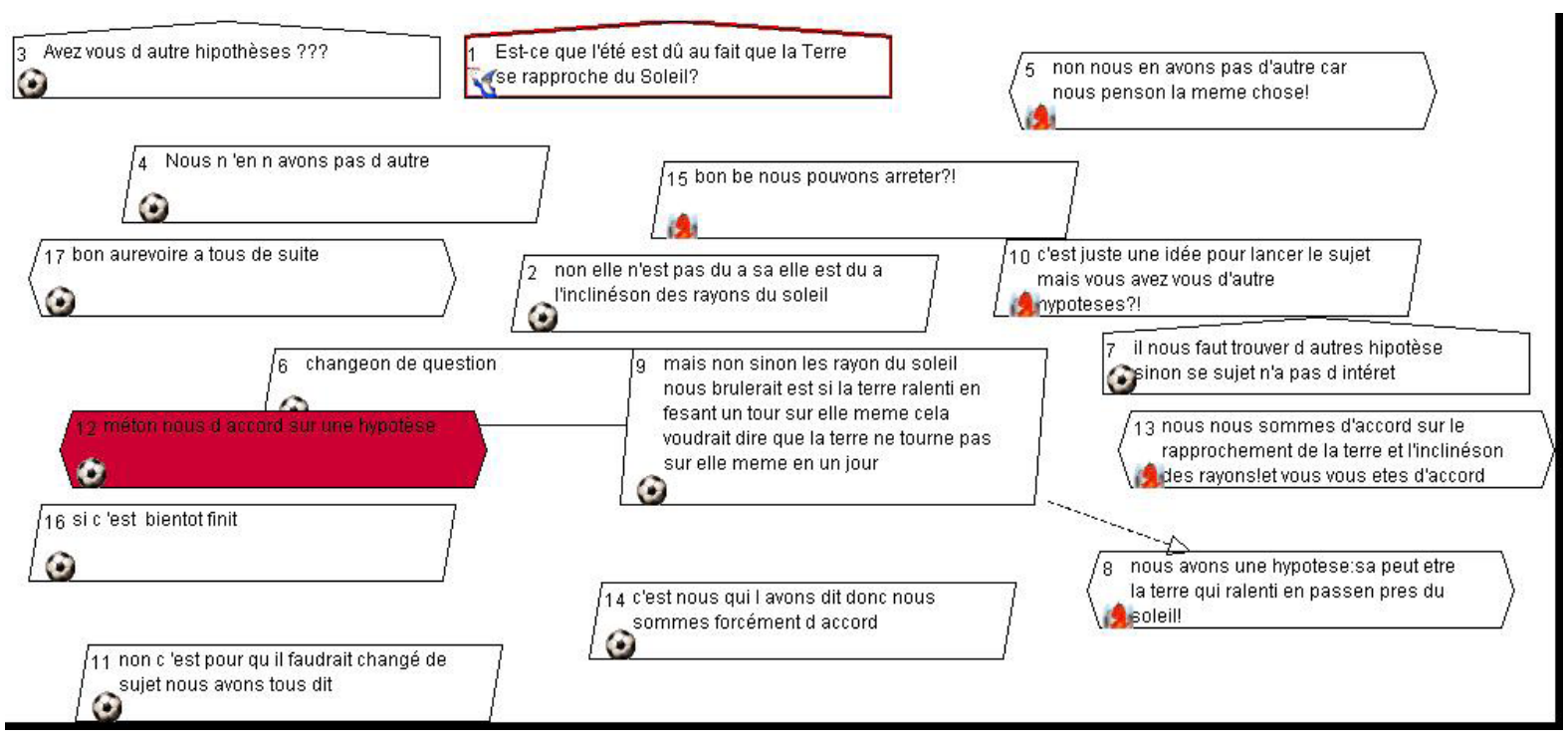

Figure 5. Example of an argumentative map in the 5th grade

1. Is summer due to the fact that the Earth is nearer the Sun?

2. No, it is not due to the Earth but it is due to the angle of the sunbeams

3. do you have any other hypotheses?

4. We do not have any

5. no we do not have any because we think the same.

6. let's have another question

7. we have to find other hypotheses otherwise the subject loses its interest

8. we have a hypothesis: maybe the Earth slows down when it is near the sun.

9. But no otherwise the sunbeams would burn us and if the Earth slows down when it rotates on itself it means that the Earth rotates on itself in one day.

10. it is just an idea, do you have any other hypothesis?

11. no we could change our subject we have already said everything.

12. let's agree together on a hypothesis

13. We agree about the Earth moving closer to the sun and the angle of the sunbeams and you, do you agree?

14. It is our proposition so of course we agree!

15. so we stop

16. yes it is nearly the end

17. goodbye see you soon!

As a conclusion, the argumentative maps were not used in the same way in the three grades: it is only in grade 5 that the students engage in the dialogical dynamics of argumentation supported by Digalo where they followed the other participant's proposition, tried to agree with it or dismiss it. Some of the students in grade 4-5 and grade 5 seem to have learnt not only about the topic at stake through the different debates (small group, whole group, Digalo debate) but also to have learnt about argumentation. When only the structure of the argumentative exchanges is analysed, it is found that the grade 5 students proposed more coordinated propositions in their discussion and their propositions are also better linked and justified. Their justifications relied on scientific proof as well as on an appeal to authori- 
ty (discourse of parents, teachers, etc.) or they asked their partner to develop their viewpoint.

After having participated in this phase of discussion through Digalo, the argumentative maps produced by each school grade were re-used and re-built in order to give students the opportunity to re-use the collective debate in another activity. Two argumentative maps were constructed by the researchers in order to confront the students' knowledge about the quality of the arguments proposed in the map and the knowledge mobilized to generate the discussion: one argumentative map was a "poor" map with regard to both argumentation and knowledge mobilized, while the second map was "rich" in that opposite arguments were proposed, propositions were justified and coordinated. The students from each grade received the following instruction: read the two maps and evaluate the content and the argumentation first in the same small groups (step 5) and then discuss them in the whole-class group (step 6). It was during this last phase of debate guided by the printed map, and in particular when they examined the richer one, that the $5^{\text {th }}$-grade students engaged in a more reflexive activity and dismissed the distance explanation for the seasons.

Examining one teacher's scaffolding actions to enhance argumentation in astronomy

The teacher of the $5^{\text {th }}$ grade initiated this reflexive activity mediated by the reprinted maps. He first asked the students to work with the poor map. What was the scaffolding proposed by the teacher?

Excerpt 1: the teacher's scaffolding: towards the construction of a shared dialogical space

1. Teacher. (The teacher proposed the following activity to the students) So you will look at ... we will see what happened when you exchanged: did it go well? Are there some elements that are not good? Try to review the conversation, try to understand it. You will tell me what goes well and what is not good, are the arguments good ones or not? Are they delivered at the right moment in the discussion? Do they add something new to the debate or not? You can write on these papers if you want if you see elements that are worth discussing you can underline them, discuss them together...

2. Teacher: so we begin $<$ he reads in a loud voice $>$ the sunbeams arrive straight on the Earth in summer and that's why it is hotter in summer than in winter. What do you think about that? What sort of questions do you ask yourself? Can you remember what your hypotheses were?

A discussion began between some students and the teacher about what makes a good argument and the fact that it needs to be justified.

3. a student: (A student reads a proposition from the printed map) "but how is it possible to have more time to make a larger trajectory" (concerning the sun) and added: "it is not a good argument this one, it is a question!"

4. group of students (Then the students comment on the propositions in the poor map and finally agree that): saying we agree with this or that proposition is not a sufficient element to talk about argument or justification.

5. Another student: it is Clement's hypothesis!

6. The teacher (sums up and reformulates what happened): they asked a question and they developed another hypothesis so they began with a question and they did not find arguments they said yes, yes, it is true but even if it is true it is necessary at a certain point to say why it is true that the sunbeams arrive straight on the Earth but if you haven't got any arguments... You have no proof, "we agree with that" does not further the debate.

\section{The students approved.}

8. A student: the sun does not make a trajectory.

9. The teacher: the sun does not make a trajectory; yes so why did they propose that the sun did make a trajectory?

10. Another student: we have to speak about the Earth rather. 
11. The teacher concluded: so it is to show you that in this map there is no argument in the debate it is difficult to draw conclusions when there is no argumentation and no debate in fact... so here's another map and I want you to discuss this map together in small groups and then tell me if the arguments are good ones. Do they arrive at the right moment? Or not? etc., etc. Discuss this map together for five minutes and then we'll discuss it all together.

In excerpt 1 , the scaffolding proposed by the teacher relies on reformulation and making explicit the work that has to be done both conceptually (for example when he asked "why did they propose that the sun did make a trajectory"; excerpt 1,9) and dialogically or argumentatively (excerpt 1,11). He tried to lead the students to confront their knowledge about whether it is the Earth or the Sun that moves and their relations. By asking questions or asking for clarification, he co-constructed with them a common background to examine the seasons. Progressively the students engaged in a debate on the sun's apparent movement and the fact that only the Earth moves. Later they examined the movements of the Earth: does the Earth tilt ("bascule" in French)? and then the speed of the Earth (speed of rotation or revolution?) as possible ways to explain the seasons. The teacher's reformulations and clarifications lead the students to construct a shared space of discussion and allow them progressively not to find one answer but to dismiss unsatisfactory ones. Once this space has been co-constructed, the teacher provides another form of scaffolding by letting them work in small groups: peer-work mediated by the map.

The teacher led the students to be able to co-construct criteria to evaluate the others' explanations; these criteria became shared rules for the group and sometimes for the class community when the students presented them in the whole class debate and when the teacher focused on them and asked for discussion.

\section{Discussion}

Results showed that elementary students guided by their teacher are able to use argumentative maps in order to engage in a discursive practice of science, in this case astronomy. Most research has focused on more advanced students so it is interesting to see that elementary school students and particularly $5^{\text {th }}$ grade students begin to engage in dialogical uses of mapping the different explanations of the seasons. Through oral dialogues and dialogues mediated by argumentative maps and by the teacher's scaffolding, they progressively scrutinized the different explanations as well as the ways of expressing them in a debate. Participating in an argumentative map construction to learn about the seasons seems to be more difficult for grade 3 students. The argumentative strategies used in the argumentative maps at this level consist in juxtaposing ideas rather than being able to challenge them. Subsequently, in grades 4-5 and grade 5 as the argumentation develops, the maps become richer in challenges and progressively the distance hypothesis is sidelined in their explanation of the seasons. Grade 5 students progressively engage in a more co-constructive way of negotiating meanings from a scientific perspective during the learning sequence. Participating in mapping the seasons dialogically is also transforming: from a simple inscription or projection of an idea and another one, etc. in a common space, it becomes a way of negotiating meanings with respect to certain norms that are also negotiated. The results regarding the teacher's scaffolding indicate that scaffolding intervenes at several levels. The teacher scaffolds the development of students' understanding by arranging socially and materially (Sørensen, 2009; Kontopodis \& Perret-Clermont, in print) the conflict or the tension between their level of "actual" development and the one they have to reach - the potential one (Vygotsky's (1933/1997) distinction between actual level of development and the potential one): first when he proposed a scientific schema that contradicted the most common hypothe- 
sis about the seasons (the distance one), then when he organised the peer groups with different levels of understanding of the seasons, when he confronted the peer group with another hypothesis than the one they agreed on in order to generate a new debate through Digalo argumentative maps, and also when he proposed to compare two maps as a possible way of generating another understanding and brought the students to agree on specific rules to develop a better argumentative discussion.

\section{Conclusion}

The research presented here provides different aspects of learning-teaching in innovative ways.

\section{References}

- Andriessen, J. Baker, M. \& Suthers, D. (2003). Arguing to learn: confronting cognitions in computer-supported collaborative learning environments. Dordrecht: Kluwer Academic Publishers.

- Brown, J.S., Collins, A. \& Duguid, P. (1989). Situated Cognition and the Culture of Learning, Educational Researcher, 18 (1), 32-42.

- Baucal, A. (2012). Scaffolding by design: Co-construction through interaction with culturally structured environment. In: Baucal, A. \& Radišić, J. (Eds.), Patchwork. Learning Diversities - conference proceedings (full papers) (pp. 71-79). Belgrade, Institute of Psychology.

- Baucal, A., Arcidiacono, F., \& Budjevac, N. (2013). "Is there an equal (amount of) juice?" Exploring the repeated question effect in conservation through conversation. European Journal of Psychology of Education, 28(2), 475-495.

- Bruner, J. (1996). Léducation entrée dans la culture. Paris : Retz.

- Cole, M., \& Engestrom, Y. (1995). Commentary. Human Development, 38(1), 9-24.

- Cole, M. (1996). Cultural Psychology: A once and future discipline. MA: Cambridge University Press.

- Danish, J.A. \& Enyedy, N. (2015). Latour goes to kindergarten: children marshaling allies in a spontaneous argument about what counts as science. Learning, Culture and social interaction, 5, 5-19.

- Doise, W., Mugny, G., \& Perret-Clermont, A.-N. (1975) Social interaction and the development of cognitive operations, European Journal of Social Psychology, 5, 367-383.

- Douaire, J. (Ed.) (2004). Argumentation et disciplines scolaires. Paris : INRP.

- Dunn, J. \& Munn, J. (1987). Development of justification in disputes with mother and sibling. Developmental Psychology, 23(6), 791-798.

- Engestrom, Y. (1987). Learning by expanding. An activity theoretical approach to developmental research. Helsinki: Orienta-Konsultit. 
- Engestrom, Y. (1990). Learning, working, imagining: Twelve studies in activity theory. Helsinki: OrientaKonsultit.

- Enyedy, N. (2005). Inventing mapping: creating cultural forms to solve collective problems. Cognition \& Instruction, 23(4), 427-466.

- Hutchins, E. (1995). Cognition in the wild. Cambridge, MA: MIT Press.

- Jaubert, M. (2007). Langage et construction des connaissances à l'école. Un exemple en science. Bordeaux : Presses Universitaires de Bordeaux.

- Kontopodis, M. \& Perret-Clermont, A.-. (2015, in print). Educational Settings as Interwoven Socio-Material Orderings: An Introduction. European Journal of Psychology of Education, 30(4).

- Latour, B. (1987). Science in action: how to follow scientists and engineers through society. Cambridge, MA : Harvard University Press.

- Latour, B. (1988). Drawing things together. In M. Lynch \& S. Woolgar (Eds.), Representation in scientific practice (pp. 19-68). Cambridge, MA: MIT Press.

- Lave, J. (2011). Apprenticeship in Critical Ethnographic Practice. Chicago: Chicago University Press.

- Moro, C. Schneuwly, B. \& Brossard, M. (Eds.) (1997). Outils et signes. Perspectives actuelles de la théorie de Vygotski. Berne: Peter Lang.

- Muller-Mirza, N., Perret-Clermont, A.N., Tartas, V. \& Iannaccone, A. (2009). Psychosocial processes in argumentation. In N. Muller-Mirza \& A.N Perret-Clermont (Eds.) Argumentation and education (pp.6790). London: Springer.

- Muller Mirza, N. \& Perret-Clermont, A.- N. (2008). Dynamiques interactives, apprentissages et médiations : analyses de construction de sens autour d'un outil pour argumenter. In L. Filliettaz \& M.-L. Schubauer-Leoni (Eds.) Processus interactionnels et situations éducatives. Bruxelles: De Boeck collection Raisons éducatives.

- Muller Mirza, N., Tartas, V. Perret-Clermont, A.-N. \& De Pietro, J.-F. (2007). Using graphical tools in a phased activity for enhancing dialogical skills: an example with Dunes. International Journal of ComputerSupported Collaborative Learning, 2 (2-3), 247-272.

- Perret, J.F. \& Perret-Clermont, A.-N. (2011). Perret, J.-F., \& Perret-Clermont, A.-N. (2011). Apprentice in a changing trade (N. Emler, Trans.). Charlotte, N.C. USA: Information Age Publishing.

- Perret-Clermont, A.-N. (1979/2000). La construction de l'intelligence dans l'interaction sociale. Berne : Peter Lang.

- Orsolini, M. (1993). "Dwarfs do not shoot”: an analysis of children's justifications, Cognition and instruction, 11 (3-4), 281-297.

- Resnick, L.B. (1987). Constructing knowledge in school. In L. S. Liben (Ed.), Development and learning: conflict or congruence? (pp. 19-50). Hillsdale, NJ: Lawrence Erlbaum Associates.

- Roschelle, J. (1994). Designing for cognitive communication: epistemic fidelity or mediating collaborative inquiry? The electronic journal of virtual culture, 2(2).

- Schoultz, J., Saljo, R., \& Wyndhamn, J. (2001). Heavenly Talk: Discourse, Artifacts, and Children's Understanding of Elementary Astronomy. Human Development, 44, 103-118.

- Siegal, M., Butterworth, G. \& Newcombe, P.A.(2004). Culture and children's cosmology. Developmental Science, 7 (3), 308-324. 
- Suthers, D.D. (2003). Representational guidance for collaborative inquiry. In J. Andriessen, M. Baker \& D. D. Suthers (Eds.) Arguing to learn. Confronting cognitions in computer-supported collaborative environments (pp.27-46).. Dordrecht : Kluwer Academic Press.

- Tartas, V. \& Perret-Clermont, A.-N. (2012). Faire avec autrui une situation pour comprendre le développement. In Y. Clot (dir.), Vygotski maintenant. Paris: La Dispute.

- Tartas, V., Baucal, A. \& Perret-Clermont, A.-N. (2010). Can you think with me? The social and cognitive conditions and the fruits of learning. In C. Howe \& K. Littletown (Eds.), Educational Dialogues: Understanding and Promoting Productive Interaction (pp.64-82). London: Elsevier Advances in Learning and Instruction Book.

- Vosniadou, S., Skopeliti, I. \& Ikospentaki K. (2004). Modes of Knowing and Ways of Reasoning in Elementary Astronomy. Cognitive Development, 19, 203-222.

- Vygotski, L. S. (1931/1978). Mind in society. Cambridge, MA: Harvard University Press.

- Vygotski, L.S (1934/1985). Pensée et Langage. Paris: Editions sociales.

др Валери Тарта

Универзитет у Тулузу Жан-Жоре, Француска

\section{Учење природних наука помоћу дијалошких мапа}

Развој дечјих појмова се још увек проучава без узимања у обзир школских активности, пре свега, вербалних и инструменталних, у оквиру којих се ови појмови развијају. Ово истраживање се базира на виђењу Виготског, који дефинише мишљење и његову динамику у оквиру семиотског контекста у којем се мишљење одвија. Овај рад има за циљ да покаже како је наставник уводио ученике у усвајање учења природних наука на начин који је истраживачки и аргументован. Развијен је софтвер који подржава аргументацију и учење - аргументативна мапа која се зове Дигало, и којом се обезбеђује визуелна презентација дискусије, а користили су је ученици и наставници у учионици за учење о астрономији. Дигало допушта корисницима да конструишу мапе дијалога и тако визуализацијом дискусије која је у току, а у вези је са научним феноменом, подрже рад из природних наука. Проучавање аргументативних мапа у пракси на различитим часовима ће илустровати да ли ова врста оруђа подржава процесе ученичког разумевања и учења. Бављење астрономијом може да се дефинише као учествовање у друштвеном процесу са партнером који нема увек исто порекло, знање и теоријску подлогу, и где преговарање не мора да буде успешно због различитог културног порекла.

Подаци који су овде приказани узети су из Европског пројекта (Escalate), који има за циљ да обухвати учење природних наука кроз аргументацију и активности истраживања. (Andriessen, Baker \& Suthers, 2003; Muller Mirza \& Perret-Clermont, 2008; Muller Mirza, Tartas, Perret-Clermont \& De Pietro, 2007). Три разреда основне школе (трећи, четврти и пети) учествовала су у овом истраживању и задатак је био да објасне зашто постоје годишња доба током различитих фаза дебате које је водио наставник и које су биле потпомогнуте аргументативним мапама. 
Општи квантитативни резултати, засновани на поређењу резултата пре теста и после теста, показали су да су ученици четвртог и петог разреда унапредили знање, док ученици трећег разреда нису напредовали.

Детаљнија анализа различитих фаза истраживања је спроведена усредсређујући се на дечије разумевање годишњих доба кроз анализу њихових закључака (структуру аргументованог садржаја аргументованих мапа) и како је наставник петог разреда посматрао сесије својих ђака. Резултати су показали да ученици основне школе могу да уче из дебата које су усмерене ка аргументованим мапама и које води наставник. О улози аргументативних мапа и ограничења које намеће наставник у процесу учења и мишљења се дискутују из социокултурне перспективе.

Истраживање које је овде спроведено приказује различите аспекте учења и поучавања на иновативне начине. Прво, проучавано је како аргументоване мапе могу да се користе да би се обухватило учење и поучавање природних наука у основној школи, тема о којој се није много дискутовало у литератури. Друго, наглашена је потреба да се дефинишу активности поучавања и учења као заједничке (а да се не проучава развој појмова код ученика независно од активности наставника). Закључак је да могућност да ученици имају прилику да поново користе заједничку елаборацију може да буде занимљива иновација у поучавању, а тако би се стимулисало и њихово учешће у рефлексивним активностима.

Кључне речи: учење природних наука, аргументација, семиотичка оруђа и медијација, аргументативна мапа. 